\title{
Lunasin - a bioactive peptide from triticale (X Triticosecale Wittmack) seeds, inhibits proliferation of cancer HeLa and SK-OV-3 cells
}

\author{
Mariola E. Galbas $^{1 *}$, Filip PorzuceK ${ }^{1}$, Marek Selwet ${ }^{2}$, Agnieszka NowaK ${ }^{1}$, Ryszard Slomski ${ }^{1}$ \\ ${ }^{1}$ Department of Biochemistry and Biotechnology, Faculty of Agronomy and Bioengineering, \\ Poznań University of Life Sciences, Poznań, Poland \\ ${ }^{2}$ Department of General and Environmental Microbiology, Faculty of Agronomy and Bioengineering, \\ Poznań University of Life Sciences, Poznań, Poland
}

\begin{abstract}
The presented study demonstrates the influence of lunasin, a bioactive peptide isolated from seeds of winter triticale, on the proliferation of neoplastic cells. In order to conduct investigations, $2 \mathrm{~S}$ fraction low-molecular-weight albumin proteins were extracted. SDS-PAGE electrophoresis separation of extracts indicated the presence of a $5 \mathrm{kDa}$ peptide in the crude extract, which corresponded to the weight of lunasin. The next stage of protein purification involved ion-exchange column chromatography in an FPLC system on DEAE Sepharose Fast Flow. The separation of biomolecules by means of 2D electrophoresis confirmed that a peptide with an isoelectric point was present in the area, with a $\mathrm{pH}$ of about 5.5 and molecular mass of about $5 \mathrm{kDa}$. The presence of lunasin in the purified samples was confirmed by Western blot. The lunasin peptide affected the proliferation of cervical cancer (HeLa) and ovarian cancer (SK-OV-3) cell lines. The average decrease in the HeLa cell proliferation rate was 17\%. The SK-OV-3 cell line was more susceptible to inhibition by the protein fraction containing lunasin than HeLa cells, with an average decrease in the proliferation rate of $48 \%$.
\end{abstract}

Key words: triticale, lunasin, Western blotting, HeLa, SK-OV-3 cell lines

\section{Introduction}

The presence of bioactive proteins and peptides in a diet is essential for human health (Rutherfurd-Markwick, 2012). Scientists have focused particular attention on soybean, because it is a rich source of proteins and lipids. In the late 1990s, Galvez and coworkers (1991, 2001) demonstrated the presence of a $5 \mathrm{kDa}$ peptide in soybean, which was a smaller subunit of the $2 \mathrm{~S}$ albumin - (Gm2-S1). The peptide called lunasin has a sequence of 43 amino acids and a characteristic arginine-glycineaspartic acid motif (RGD). Interestingly, the presence of this motif in lunasin leads to the apoptosis of L1210 leukemia cells by the activation of caspase-3. Lunasin may also interact with $\alpha \mathrm{V} \beta 3$ integrin and inhibit Akt-mediated NF- $\kappa B$ activation (de Mejia et al., 2010). Interestingly, the presence of the same RGD motif in membrane pro- teins of neoplastic cells enables them to invade healthy cells (Cam et al., 2012). Lunasin can compete with neoplastic cells and prevents them from binding to extracellular matrix proteins (Hernández-Ledesma et al., 2012). This mechanism is a key factor in the inhibition of metastases. Moreover, lunasin causes mitotic disorders in the apoptosis of cells treated with a carcinogen, as demonstrated by Jeong (2010). Lunasin has also been proved to affect disorders in DNA transcription by inhibiting acetylation of histones $\mathrm{H} 3$ and $\mathrm{H} 4$ in humans. This interrupts mitotic divisions and ultimately leads to cell death (Galvez et al., 2001; Jeong et al., 2007). Moreover, lunasin as a bioactive peptide is capable of reducing the level of low-density lipoprotein (LDL) cholesterol, and acts as an anti-carcinogen, anti-inflammatory and anti-oxidant agent (Hernández-Ledesma et al., 2009;

\footnotetext{
* Corresponding author: Department of Biochemistry and Biotechnology, Faculty of Agronomy and Bioengineering, Poznań University of Life Sciences, Dojazd 11, 60-632 Poznań, Poland; e-mail: mariolagalbas@gmail.com
} 
Garcia-Nebot et al., 2014). Finally, tests on animals have proved that orally administered lunasin reaches its target cells without any negative effect on the morphology and proliferation of healthy cells. The bioavailability and bioactivity of this peptide determine its high potential as a dietary supplement (Hernández-Ledesma et al., 2009; Hsieh et al., 2011). So far, lunasin has been isolated from rye (Jeong et al., 2009), barley (Jeong et al., 2010), and oat (Nakurte et al., 2013) and it has been found in plants of the Solanaceae family (Jeong et al., 2010). Recently, this chemopreventive peptide has been demonstrated in seeds of triticale (Nakurte et al., 2012).

The aim of our study was to purify the $2 \mathrm{~S}$ albumin fraction containing lunasin from the Polish winter triticale cultivar Gniewko and to investigate its effect on neoplastic cell lines of cervical cancer (HeLa) and ovarian cancer (SK-OV-3).

\section{Materials and methods}

\section{Isolation of low molecular weight albumins from triticale seeds}

Optimization of protein isolation from triticale (x Triticosecale Witt.) seeds was based on the starting procedure developed by Seber and coworkers (2012) with modifications (Galbas et al., 2013). The method was optimized in terms of the applied buffer type, temperature and the duration of the isolation process. Initial laboratory tests showed that the method with $0.05 \mathrm{M}$ Tris $\mathrm{HCl} \mathrm{pH} 8.5$ buffer was the most efficient for the isolation of the $2 \mathrm{~S}$ albumin fraction from triticale, as compared with isolation in PBS (Phosphate-buffered saline) or distilled water. Seeds were mechanically fragmented and flour portions of $10 \mathrm{~g}$ were weighed. Flour was shaken for 1 or $2 \mathrm{~h}$ at room temperature in $40 \mathrm{ml}$ of $0.05 \mathrm{M}$ Tris-HCl pH 8.5 buffer, in water or in PBS. The resulting samples were centrifuged at $17640 \mathrm{~g}$ for $30 \mathrm{mi}-$ nutes. The precipitate was discarded, while the resulting supernatant was extracted with cyclohexane and then was cleared by centrifugation at $17640 \mathrm{~g}$ for 5 minutes. The upper layer was discarded and the lower layer was collected. The concentration of proteins in the samples was measured by the tannin method (Mejbaum-Katzenellenbogen, 1955). Then, crude extracts were separated in a $15 \%$ polyacrylamide gel (Tris-Tricine) in the presence of SDS at $4^{\circ} \mathrm{C}$. The gel was stained with Coomassie Brilliant Blue. Additionally, crude extracts were further purified by ion-exchange chromatography on

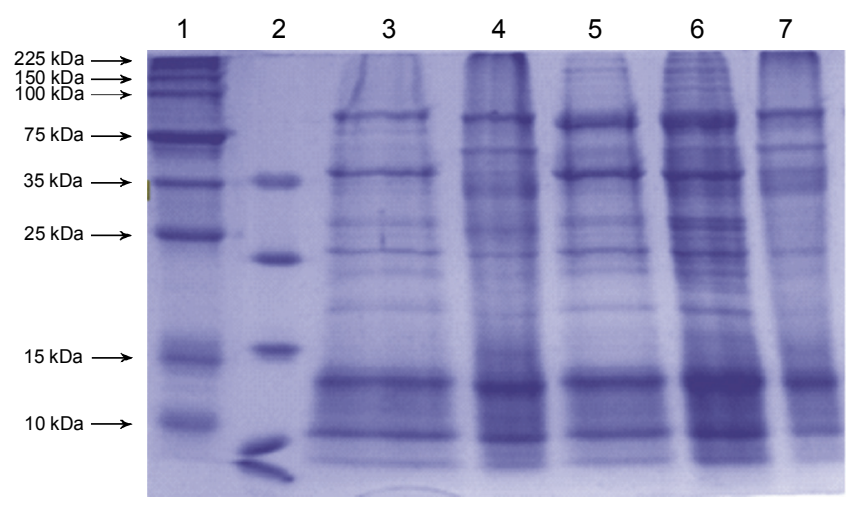

Fig. 1. SDS/PAGE pattern profiles of crude extracts of triticale proteins. Lanes: 1 - molecular weight marker (Broad Range protein Molecular Weight Markers Promega); 2 - molecular weight marker (Page Ruler Unstained Low Range protein Ladder: 1.7, 4.6, 10, 15, 25, $40 \mathrm{kDa}$ ThermoScientific); 3 - water extract $/ 1 \mathrm{~h} / 4^{\circ} \mathrm{C} ; 4$ - PBS extract $/ 24 \mathrm{~h} / 4^{\circ} \mathrm{C} ; 5$ - PBS extract $/ 1 \mathrm{~h} / 4^{\circ} \mathrm{C} ; 6$ - Tris- $\mathrm{HCl} \mathrm{pH} 8.5$ extract $/ 24 \mathrm{~h} / 4^{\circ} \mathrm{C} ; 7$ - Tris$\mathrm{HCl} \mathrm{pH} 8.5$ extract $/ 1 \mathrm{~h} / 4^{\circ} \mathrm{C}$

a DEAE Sepharose Fast Flow in the FPLC system (Pharmacia LKB). The following two buffers were used for separation: buffer A ( $50 \mathrm{mM}$ Tris- $\mathrm{HCl} \mathrm{pH} \mathrm{8.0)} \mathrm{and} \mathrm{buffer}$ B (50 mM Tris- $\mathrm{HCl} \mathrm{pH} \mathrm{8.0,1M} \mathrm{NaCl).} \mathrm{The} \mathrm{column} \mathrm{was}$ balanced with buffer $\mathrm{A}$ and a $4 \mathrm{ml}$ sample was placed on it. A linear gradient of increasing $\mathrm{NaCl}$ concentrations was set (buffer B). The flow was set at $2 \mathrm{ml} \mathrm{min}^{-1}$. Two $\mathrm{ml}$ protein fractions were collected. Finally, the fractions were dialyzed at $4{ }^{\circ} \mathrm{C}$. The concentration of proteins from individual peaks was measured by the tannin method. Redundant proteins were eliminated by ultrafiltration in Amicon ${ }^{\circledR}$ Ultra 30K test tubes (Millipore). Then, the samples were concentrated by acetone precipitation and electrophoresis was carried out again in 15\% SDS/PAGE gel. The results were additionally imaged by means of 2D bidirectional electrophoresis. Isoelectric focusing was carried out on $20 \mathrm{~cm}$ strips, $\mathrm{pH}$ 3-10 (Serva) in an Ettan IPGphor 3 IEF System (GE Healthcare Life Sciences). The fractions obtained after chromatography on the DEAE Sepharose Fast Flow were collected for further analysis. The presence of lunasin in the purified fraction was confirmed by Western blotting. Primary antibodies were supplied by Eurogentec. 1:5000 dilution of primary antibodies was used. Next, the membrane was rinsed with TBST (Tris-Buffered SalineTween) buffer and incubated with Peroxidase-conjugated AffiniPure $\mathrm{F}\left(\mathrm{ab}^{\prime}\right)$ secondary antibodies $(1: 5000)$ (Jackson ImmunoResearch). Chemiluminescent detection was 


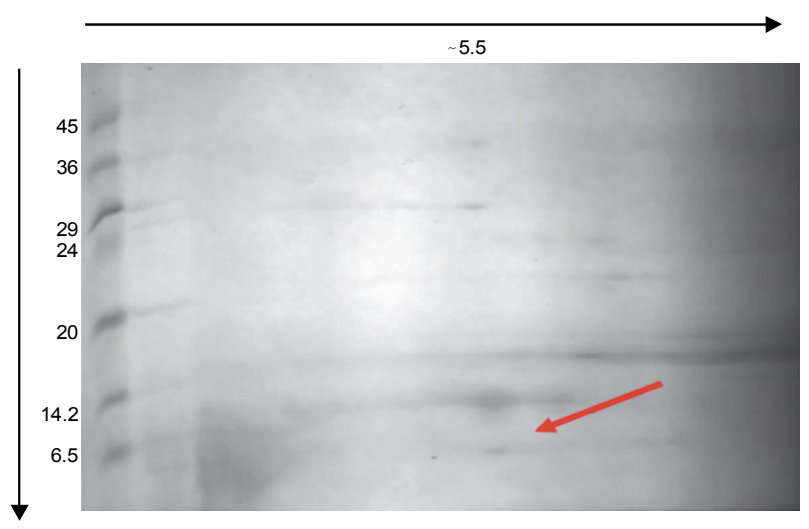

Fig. 2. The 2D electrophoretic image of the fraction with the highest protein concentration (No. 5) obtained after chromatography on the DEAE Sepharose Fast Flow. The arrow points to the peptide, which molecular weight and $\mathrm{pH}$ value corresponding to lunasin

performed using LumiGLO reagent (Cell Signaling) and chemiluminescent imaging was carried out with the c500 Infrared Imaging System (Azure Biosystems).

The effect of the lunasin containing fraction on neoplastic cells was investigated after an additional dialysis in a PBS buffer at $4^{\circ} \mathrm{C}$ performed overnight. The HeLa and SK-OV-3 cell lines grew adhesively on a DMEM medium with 10\% FBS (Fetal Bovine Serum) and 1\% antibiotic antimycotic solution (Merck) added. The cultures were incubated at $37^{\circ} \mathrm{C}$ and $5 \%$ carbon dioxide concentration. The count of cells grown was determined in a Bürker chamber. Cells of both cell lines were cultured on 96-well plates. Initially, $100 \mu \mathrm{l}$ of the cell suspension (1000 cells) was dispensed into each well and absorbance was measured at a wavelength of $450 \mathrm{~nm}$. Next, $10 \mu \mathrm{l}$ of the fraction containing lunasin was added into each well and cells were incubated at $37^{\circ} \mathrm{C}$ and $5 \%$ carbon dioxide. Cell viability was quantified with a Cell Counting Kit-8 after 6, 24 and 48 hours.

\section{Results}

During the study, the albumin proteins of triticale were isolated with different solvents: $0.05 \mathrm{M}$ Tris $\mathrm{HCl}$ $\mathrm{pH} 8.5$ buffer, Phosphate-buffered saline (PBS) and water (Table 1). Protein concentrations in crude extracts were measured by the tannin method and the results were used to assess the efficiency of isolations carried out with different reagents.

The greatest amount of proteins (Table 1) from triticale seeds was obtained using the isolation method
Table 1. Results of spectrophotometric measurements of crude protein extracts obtained from seeds of triticale cv. Gniewko using the tannin method

\begin{tabular}{l|c}
\hline $\begin{array}{c}\text { Extracting } \\
\text { buffer }\end{array}$ & $\begin{array}{c}\text { Protein concentration } \\
{[\mathrm{mg} / \mathrm{ml}]}\end{array}$ \\
\hline Tris-HCl/1h & 19.07 \\
\hline PBS/1h & 18.38 \\
\hline Water $/ 1 \mathrm{~h}$ & 13.65 \\
\hline
\end{tabular}

with $0.05 \mathrm{M}$ Tris- $\mathrm{HCl} \mathrm{pH} 8.5$ buffer and simultaneous intensive shaking at $4{ }^{\circ} \mathrm{C}$.

The SDS-PAGE analysis showed no significant changes in the profiles of protein fractions resulting from the application of a particular reagent during the isolation procedure. Further analyzes were conducted on extracts obtained with $0.05 \mathrm{M}$ Tris- $\mathrm{HCl} \mathrm{pH}$ 8.5. The application of DEAE Sepharose Fast Flow anion-exchange column chromatography in the FPLC system provided further purification of the proteins (Table 2). Fractions were collected, with the buffer $\mathrm{B}$ percentage content ranging from $45 \%$ to $60 \%$.

Table 2. Concentrations of proteins in individual fractions obtained during chromatographic separation on the DEAE Sepharose Fast Flow

\begin{tabular}{c|c}
\hline $\begin{array}{c}\text { Fraction } \\
\text { number }\end{array}$ & $\begin{array}{c}\text { Protein concentration } \\
{[\mathrm{mg} / \mathrm{ml}]}\end{array}$ \\
\hline 1 & 0.47 \\
\hline 2 & 1.081 \\
\hline 3 & 0.665 \\
\hline 4 & 0.459 \\
\hline 5 & 0.496 \\
\hline
\end{tabular}

The qualitative analysis of the chromatographic separation was carried out by electrophoresis in $12 \%$ SDS/PAGE gel.

The electrophoretic image of fractions obtained after chromatography showed the presence of proteins of molecular weights between 2 and $20 \mathrm{kDa}$. These were eliminated by ultrafiltration on Millipore columns. The effectiveness of the procedure was examined by means of $2 \mathrm{D}$ electrophoresis.

The presence of lunasin in fraction No. 5 was confirmed by the Western blot method (Fig. 3). 
A

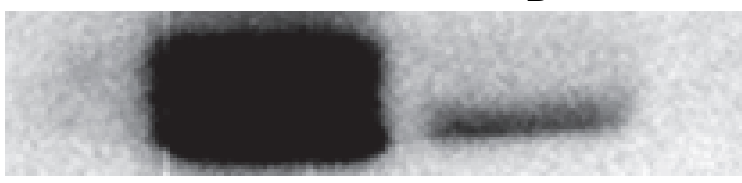

Fig. 3. Detection of lunasin using Western blot. Track A - a purified peptide fraction from mature soybean seeds containing lunasin, track B - a purified peptide fraction from triticale

\section{Proliferation test}

The HeLa and SK-OV-3 cell growth was analyzed using the Cell Counting Kit 8 (CCK 8) viability assay. The cells were treated with purified fractions containing lunasin. Lunasin containing fractions (protein stock solution $0.49 \mathrm{mg} / \mathrm{ml}$ ) was added to the growing cell cultures (ten-fold and twenty-fold dilution). In comparison with the control sample (non-treated), the HeLa neoplastic cell proliferation test showed a decrease in the rate of cell proliferation in samples treated with fractions containing lunasin. The greatest decrease in absorbance was observed 24 hours after the beginning of cell incubation with the purified $2 \mathrm{~S}$ fraction. The test showed that the fraction at the concentration of $0.049 \mathrm{mg} / \mathrm{ml}$ reduced HeLa cells proliferation by $28 \%$ after 48 hours.

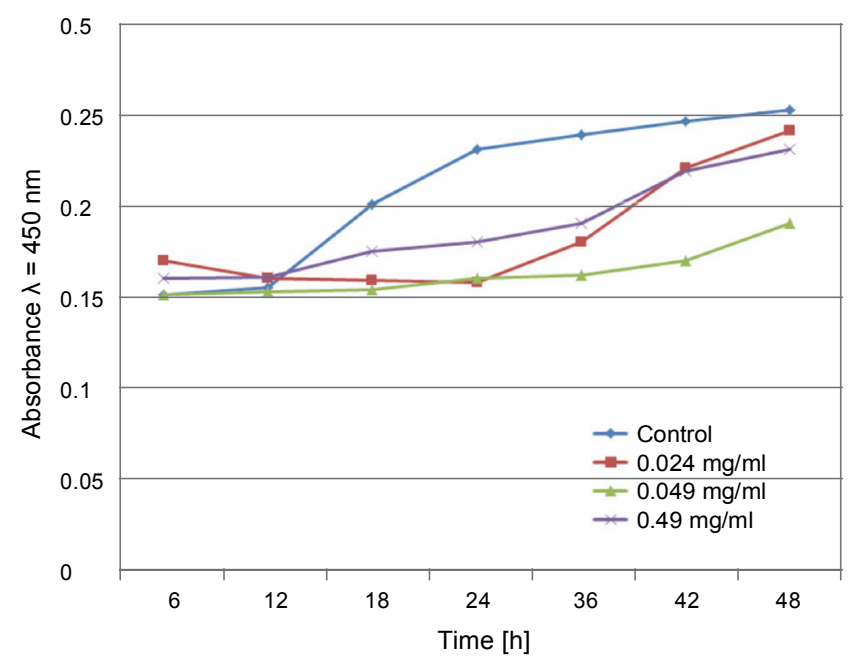

Fig. 4. Variation in the proliferation rate of HeLa line cells incubated with the protein fraction containing lunasin

The CCK 8 test showed that the proliferation rate of SK-OV-3 neoplastic cells decreased considerably after lunasin application. The fraction at the concentration of $0.024 \mathrm{mg} / \mathrm{ml}$ proved to be the most effective. The fraction containing lunasin inhibited cell growth by $43 \% \mathrm{du}$ ring the first 6 hours, by $56 \%$ after 12 hours and by $45 \%$ after 48 hours.

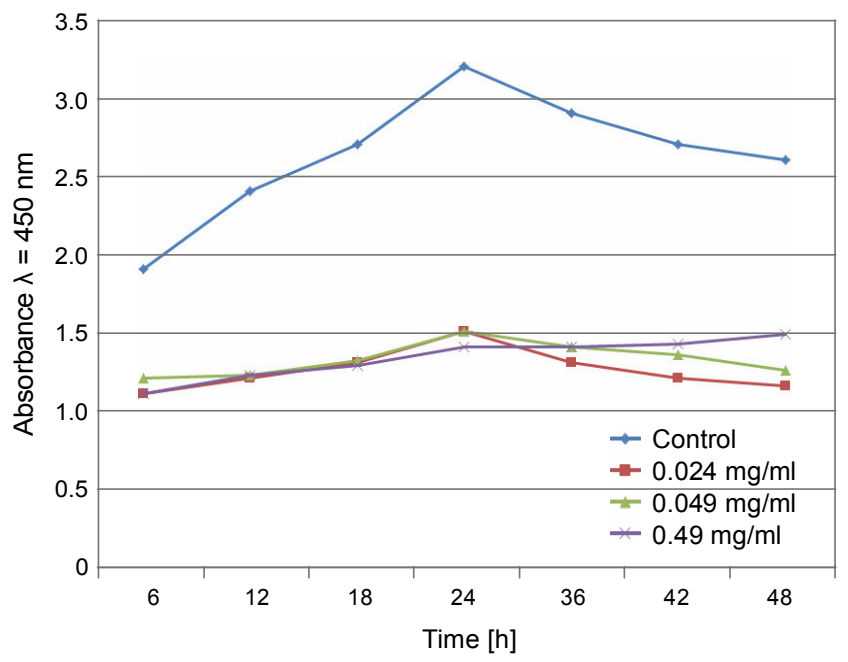

Fig. 5. Variation in the proliferation rate of SK-OV-3 line cells incubated with the fraction containing lunasin

\section{Discussion}

Currently, the search for bioactive peptides is of great significance and is the main aim of nutrigenomics. Such health-promoting compounds include some peptides found among low-molecular-weight proteins isolated from the albumin fraction of plants such as soybean, rice or wheat. Numerous in vitro and in vivo studies have confirmed the anti-neoplastic, anti-inflammatory and anti-oxidative properties of lunasin (Hernández-Ledesma et al., $2009 \mathrm{~b})$. These properties play a vital role in cancer treatment and have a positive influence on the cardiovascular system. Moreover, the bioactivity of this peptide has been proven, which points to its high potential as a dietary supplement (Lule et al., 2015). The general assumption that triticale has a high nutritional potential has been supported by the presence of lunasin in this cereal (Nakurte et al., 2012). However, so far the bioactivity of the triticale fraction containing lunasin toward cancer cells has not been tested. According to literature sources, extractions using distilled water and ethyl alcohol are frequently applied methods for the isolation of proteins from cereal seeds. In this study, $0.05 \mathrm{M}$ Tris- $\mathrm{HCl}$ $\mathrm{pH} 8.5$ was used for protein extraction. The consecutive stages of crude extract purification, such as DEAE Sepharose Fast Flow anion-exchange column chromatography, enabled us to obtain a relatively pure $2 \mathrm{~S}$ lowmolecular-weight protein fraction containing lunasin. The presence of lunasin in the obtained fraction was confirmed using Western Blotting semi-dry transfer on the PVDF membrane. The reaction was run using lunasin 
C-terminal primary antibodies synthesized by Eurogenteec (aa 22-37: NH2-CEKHIMEKIQGRGDDD-CONH2). $1 \%$ BSA was used to stop the reaction. The reaction was visualized using the luminol-based chemiluminescent substrate LumiGLO by Cell Signaling Technology (CST). The image was documented in the fluorescence and chemiluminescence systems by Azure Biosystems. The influence of the purified fraction on the rate of neoplastic cell proliferation was analyzed on 2 neoplastic lines: HeLa (ATCC CCL-2 and SK-OV-3 (ATCC HTB-77). The purified $2 \mathrm{~S}$ protein fraction reduced the proliferation rate of the neoplastic HeLa line. The fraction with the protein concentration of $0.049 \mathrm{mg} / \mathrm{ml}$ had the greatest effect on cell proliferation. After 24 hours, the proliferation rate dropped by $28 \%$ and after 48 hours it decreased by a further $25 \%$. In comparison with the non-treated sample, there were no changes in the cell proliferation rate observed during the first 6 hours. During the whole experiment (48h), the average decrease in the HeLa cell proliferation rate was $17 \%$. The SK-OV-3 cell line appeared to be more susceptible to the inhibition of the proliferation rate by the low-molecular-weight fraction containing luna$\sin$. The greatest decrease in the proliferation rate was observed at the protein concentration of $0.024 \mathrm{mg} / \mathrm{ml}$. The fraction inhibited cell proliferation by $43 \%$ during the first 6 hours, by $56 \%$ after 12 hours and by $45 \%$ after 48 hours, respectively. The average decrease in the proliferation rate was $48 \%$.

Publications presenting data on the influence of lunasin on the inhibition of cell proliferation in leukemia indicate the concentration of $0.3 \mu \mathrm{g} / \mathrm{ml}$ as optimal (de Mejia et al., 2010). Moreover, this bioactive peptide is a promising chemopreventive factor. Cereals are the main sources of energy in the human diet, but little is known about their role in human nutrition, especially in cancer prophylaxis. Triticale is promising cereal with a favourable chemical composition and good nutrition value. However, Alaswad and Krishnan (2016) denied the occurrence of lunasin in Triticale. The presence of lunasin, which was identified in triticale seeds used in our experiment, confirms the nutritional value of the cereal and contributes to a greater interest in the crop as a potential cereal which could be used in the human diet more widely, rather than as animal feed only. A study by Jeong (2007) showed that an appropriate diet enriched in bioactive compounds may prevent mutations which cause excessive cell proliferation. Consumption of food rich in lunasin plays a significant role in cancer prophylaxis.

\section{References}

Alaswad A.A., Krishnan H.B. (2016) Immunological investigation for the presence of lunasin, a chemopreventive soybean peptide, in the seeds of diverse plants. J. Agric. Food Chem 64: 2901-2909.

Cam A., de Mejia E.G. (2012) RGD-peptide lunasin inhibits Akt-mediated $N F * B$ activation in human macrophages through interaction with the $\alpha$ VB3 integrin. Mol. Nutr. Food Res. 56: 1569-1581.

De Mejia E.G., Wang W., Dia V.P. (2010) Lunasin, with an arginine-glycine-aspartic acid motif, causes apoptosis to L1210 leukemia cells by activation of caspase-3. Mol. Nutr. Food Res. 54: 406-414.

Galbas M., Porzucek F., Woźniak A., Słomski R., Selwet M. (2013) Isolation of low-molecular albumins of 2S fraction from soybean (Glycine max (L.) Merrill). Acta Biochim. Pol. 60: 107-110.

Galvez A.F., de Lumen B.O. (1999) A soybean cDNA encoding a chromatin binding peptide inhibits mitosis of mammalian cells. Nat. Biotechnol. 17: 495-500.

Galvez A.F., Chen N., Macasieb J., de Lumen B.O. (2001) Chemopreventive property of a soybean peptide (lunasin) that binds to deacetylated histones and inhibits acetylation. Cancer Res. 61: 7473-7478.

Garcia-Nebot M.J., Recio I., Hernandez-Ledesma B. (2014) Antioxidant activity and protective effects of peptide lunasin against oxidative stress in intestinal Caco-2 cells. Food Chem. Toxicol. 65: 155-161.

Hernández-Ledesma B., de Lumen B.O. (2008) Lunasin: a novel cancer preventive seed peptide. Perspect. Medicin. Chem. 2: 75-80.

Hernández-Ledesma B., Hsieh C.C., de Lumen B.O. (2009a) Antioxidant and anti-inflammatory properties of cancer preventive peptide lunasin in RAW 264.7 macrophages. Biochem. Biophys. Res. Commun. 390: 803-808.

Hernández-Ledesma B., Hsieh C.C., de Lumen B.O. (2009b) Lunasin, a novel seed peptide for cancer prevention. Peptides 30: 426-430.

Hsieh C., Hernández-Ledesma B., de Lumen B.O. (2011) Lunasin, a new breast cancer chemopreventive seed peptide. [in:] Breast cancer current and alternative therapeutic modalities. Ed. Esra Gunduz Mahmet Gunduz. InTech. 11: 215-242.

Jeong H.J., Jeong J.B., Kim D.S., de Lumen B.O. (2007) Inhibition of core histone acetylation by the cancer preventive peptide lunasin. J. Agric. Food Chem. 55: 632-637.

Jeong H.J., Leea J.R., Jeong J.B., Park J.H., Cheong Y., de Lumen B.O. (2009) The cancer preventive seed peptide lunasin from rye is bioavailable and bioactive. Nutr. Cancer. 61: 680-686.

Jeong J.B., De Lumen B.O., Jeong H.J. (2010a) Lunasin peptide purified from Solanum nigrum $L$. protects $D N A$ from 
oxidative damage by suppressing the generation of hydroxyl radical via blocking fenton reaction. Cancer Lett. 293: 58-64

Jeong H.J, Jeong J.B., Hsieh C.C., Hernández-Ledesma B., de Lumen B.O.(2010b) Lunasin is prevalent in barley and is bioavailable and bioactive in in vivo and in vitro studies. Nutr. Cancer. 62: 1113-1119.

Lule V.K., Garg S., Pophaly S.D., Hitesh Tomar S.K. (2015) Potential health benefits of lunasin: a multifaceted soyderived bioactive peptide. J. Food Sci. 80: 485-494.

Mejbaum-Katzenellenbogen W. (1955) Turbidimetric micromethod of determination of proteins with tannin. Acta Biochim. Pol. 2(3): 279-296.

Nakurte I., Klavins K., Kirhnere I., Namniece J., Adlere L., Matvejevs J., Kronberga A., Kokare A., Strazdina V., Legz- dina L., Muceniece R. (2012) Discovery of lunasin peptide in triticale ( $X$ Triticosecale Wittmack). J. Cereal Sci. 56: 510-514.

Nakurte I., Kirhnere, I., Namniece J., Saleniece K., Krigere L., Mekss P., Vicupe Z., Bleidere M., Legzdina L., Muceniece R. (2013) Detection of the lunasin peptide in oats (Avena sativa L). J. Cereal Sci. 57: 319-324.

Rutherfurd-Markwick K.J. (2012) Food proteins as a source of bioactive peptides with diverse functions. Br. J. Nutr. 108: 149-57.

Seber L.E., Barnett B.W., McConnell E.J., Hume S.D., Cai J. (2012) Scalable purification and characterization of the anticancer lunasin peptide from soybean. PLoS ONE 7(4): e35409. 